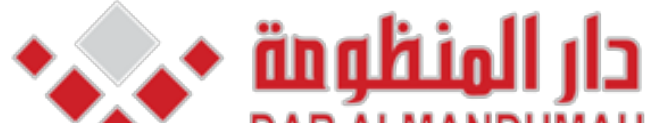 DAR ALMANDUMAH

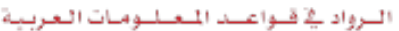

Disclosure Attributes Impact of Corporate Governance Auditing Quality and Voluntary Disclosures on the Financial Performance of Banks Listed in

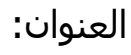
the Egyptian Stock Exchange Market

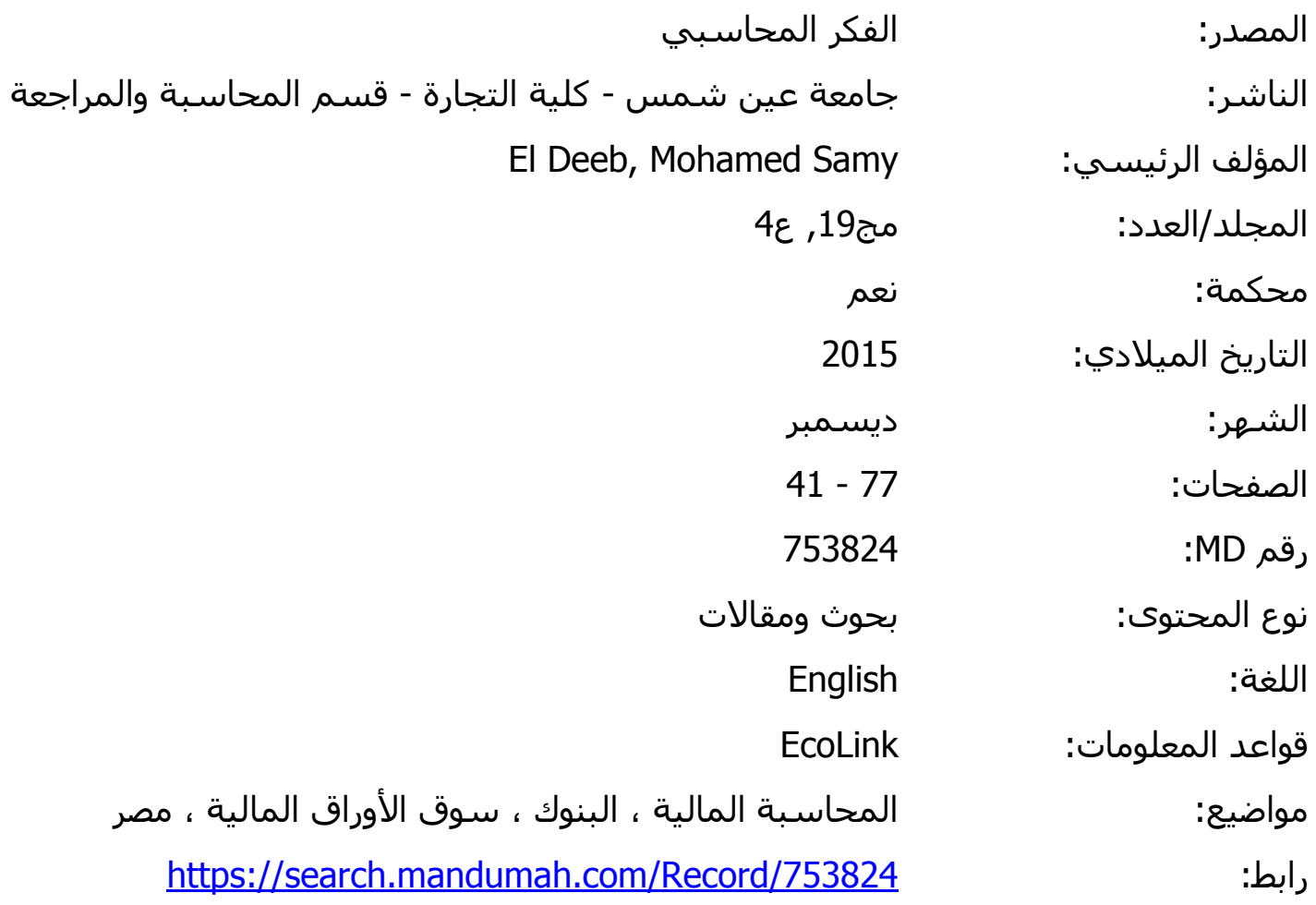


Disclosure attributes impact of corporate governance, auditing quality, and voluntary disclosures on the financial performance of banks listed in the Egyptian stock exchange market

Mohamed Samy El-Deeb,

Accounting Lecturer, PhD

Accounting Department, Faculty of Management Sciences

Modern Sciences and Arts University, Egypt 


\title{
Disclosure attributes impact of corporate governance, auditing quality, and voluntary disclosures on the financial performance of banks listed in the Egyptian stock exchange market
}

\author{
Mohamed Samy EI- Deeb,
}

Accounting Lecturer, PhD

\section{Accounting Department, Faculty of Management Sciences Modern Sciences and Arts University, Egypt Moh.eldeeb2@hotmail.com,msamy@msa.eun.eg}

\begin{abstract}
:
Banks in Egypt have unique characteristics that makes its micro economic role vital in the macro economy throughout their financial performance impact on the investors' decisions in the capital exchange market. The research investigates assesses, and discusses the appropriate disclosure attributes of banks, and disclosure attributes impact of corporate governance, audit quality, along with the voluntary disclosure attributes on the financial performance of the Islamic and non-Islamic banks in the Egyptian exchange market through an empirical research applied on banks listed in the stock exchange market. The corporate governance disclosure attributes presented by the research included Audit committee dimensions: Audit committee size, AC autonomy, AC meetings, Board size, Board independence, Managerial ownership, and other prominent variables. The audit quality disclosure attributes addressed by the research divided into two subcategories, Auditing firms determinates and Audit process determinates.
\end{abstract}

The attributes used to measure the level of voluntary disclosure includes, Internet reporting, brief history of the bank, directors skills and experiences, environment protection programs and other variables. The financial performance of banks are measured through the price earnings ratio, return on total assets, total asset growth, net profit growth and EPS ratio calculated based on the annals of the annual reports of the selected banks. The research uses the secondary data from the annual reports of the banks, and the disclosure books brought from the websites of the banks or purchased through Egypt for Information Dissemination Company. The research will cover a period starting from 2004 until 2014 (according to the availability of the data and the date of registration of the banks in the stock market) along 12 banks listed in the Egyptian stock market. The sample of the 12 banks included 3 Islamic banks and 9 non-Islamic banks. 
The research results supported the hypothesis of the research that the corporate governance, audit quality and voluntary disclosure have an impact on the financial performance of the Islamic and the non-Islamic banks with different level of significance. The empirical study of this research has been conducted using the SPSS package along with other statistical techniques to verify the hypotheses. The results of the research may have some important implications for enhancing the disclosure attributes of the Islamic banks and non-Islamic banks, which will lead to better financial performance for both categories of banks.

\section{Keywords:}

Audit quality, voluntary disclosure, corporate governance, financial performance, Egyptian banks

\section{Research Problems:}

Due to the special nature of the services provided by the banks and the heavy regulations imposed on them especially by the central bank, and the Egyptian financial supervisory authority a special attention should must be drawn to the types of disclosures made by the listed banks and their effect on the financial performance of the banks. The research is addressing the impact of the disclosure attributes of corporate governance, audit quality and voluntary disclosure on the financial performance of the banks in the Egyptian stock exchange market.

\section{Purpose:}

The research directs the attention towards the importance of disclosure attributes of corporate governance, and audit quality along with the voluntary disclosures and their impact on the financial performance of Islamic and non-Islamic banks in the stock exchange market. The research tries to fill the gap in the literature regarding the impact of disclosure attributes of corporate governance, audit quality, and voluntary disclosure on the financial performance of Islamic and non-Islamic banks listed in the Egyptian stock market.

The researcher presented the components (measures) of the selected variables based on the literature review based on a group of interviews with CPAs in the Big 4 auditing firms and with corporate governance experts in Egyptian banks in order to be familiar with the real world practice and applications of the research variables. The research examines the impact of disclosure attributes on both bank-groups in terms of its return on investments, return on assets, and other performance indicators derived from the annual reports of banks. 


\section{Research Objectives:}

This research aims to addressing and achieving the following objectives:

- Measuring the impact of the disclosure attributes of corporate governance on the financial performance of Islamic and non-Islamic banks listed in the Egyptian stock market.

- Testing the impact of the audit quality disclosure attribute on the financial performance of Islamic and non-Islamic banks listed in the Egyptian stock market.

- Measuring the impact of the voluntary disclosures attributes on the financial performance of Islamic and non-Islamic banks listed in the Egyptian stock market.

\section{Hypotheses:}

H 1: There is a significant positive relationship between the corporate governance disclosures attributes arid the financial performance of Islamic and nonIslamic banks

H 2: There is a significant positive relationship between the auditing quality disclosure attributes and the financial performance of Islamic and non-Islamic banks

H 3: There is a significant positive relationship between the voluntary disclosure disclosures attributes and the: financial performance of Islamic and nonIslamic banks

\section{Research Limitations:}

The results of the research based on a stratified sample of 12 banks (3 Islamic and 9 non-Islamic banks) among the listed ones in the Egyptian exchange market. The researcher used the annual reports and the disclosure books of the selected banks listed in the stock market for the period from 2004 up to 2014. Moreover, the researcher also, made a group of interviews with Auditors in the Big 4 auditing firms and corporate governance experts.

It is well acknowledge that this research is a part and a parcel of broader future research efforts that will investigate the impact of more disclosure attributes, based on other disclosure determinants researches. The use of more effective and detailed systems of disclosure in banking sectors can improve the financial performance of banks and help enhancing the decision of the users in the market 
as well. The research did not include banks that are not listed in the stock exchange market due to lack of information

\section{Introduction:}

Banking sector has a prominent vital role in the growth and stability of the Egyptian macro economy. Therefore, the constant control through monitoring and evaluation of its performance is essential. The disclosure of information is the dissemination of information by the organization to provide useful information. Due to the different types and categories of banks in the market and especially in the Egyptian macro economy, the disclosure of information by these banks can greatly affect their performance.

Banking activities are the pillar of the macro economy motivation. The banking sector functionality is to be affected by many variables, for example, corporate governance, audit quality, and voluntary disclosure and other various variables. The key players in the financial market with special emphasis on the stockholders, depositors and creditors of the banks are keen to be aware of the different variables that affect the financial performance of the listed banks in the stock exchange market. (Elbannan, M. A., and Elbannan, M. A., 2015)

During the latest decades, the Emerging of the Islamic banking had affected greatly the Egyptian macro economy due to their capabilities in attracting more clients and affecting the acceleration of the investments of their clients. The Islamic banks had achieved a widespread on global basis even in non-Islamic countries. Many previous studies tried to identify the similarities and differences between the Islamic and non-Islamic banks trying to gain more understanding of both types of banks. (Elbannan, M. A., and Elbannan, M. A., 2015).

Disclosure defined as the . information released by the firm, as financial or nonfinancial, and voluntary or mandatory through formal or informal means. (Gibbins et al., 1990). Gray and Skogsvik, (2004) argued that voluntary disclosure is the disclosure that provides information that exceeds the obligatory information required by laws and regulations. Singhvi and Desai, (1971) also discussed that the disclosure quality is the qualitative characteristics possessed by information like completeness, accuracy and reliability. Brown and Hillegeist, (2003) also, added to these characteristics of disclosure quality the quantity of information provided, precision, and timeliness.

According to Kent and Stewart, (2008), stated that more detailed disclosures is considered as more informative than brief disclosures and this can be used as a sign of greater transparency. In the trend, and based on the claims of Bushee, (2004), that quality and quantity are attached and very hard to measure, Beretta and Bozzolan, (2008) argued that the degree of disclosure (quantity) is to be 
considered as an adequate measure of the disclosure quality.

Taking into consideration the previous studies that identified the key definitions of disclosure quality, the researcher can summarize them as precision, timeliness, accuracy, and completeness. These terms or key words used also, in the theoretical framework of financial reporting for all various types of institutions, the financial and non-financial institutions. Previous researches identified and tested many measurement variables for disclosure themes considered within the current research as the internet reporting, internal audit information, and board of directors disclosures. Cooke and Wallace, (1989), identified that the process of measuring the quality of disclosure is highly subjective and it does not have a defining characteristics as for other tangible items. The complications of defining and measuring quality of disclosure are complied with researchers who argued that no perfect measurement of disclosure quality. (Debreceny and Rahman, 2005). The quality of disclosure is impossible to measure as supported by Beretta and Bozzolan, (2008). In the context of the research, quality of disclosure is defined, as "completeness, accuracy and reliability" in compliance with Singhvi and Desai, (1971).

\section{Banking system in Egypt:}

Since the mid of 1970s, the Egyptian banking sector had expanded remarkably in compliance with the country's open door policy. The open door policy aimed to increase the role of the private sector in supporting the Egyptian macro- economic performance. Consistently with the emergence of the law no. 120/1975 that identified the nature of bank activities in Egypt. (Central Bank of Egypt, 1992).

Banking sector considered the main financial service sector that leads to the economic development and the stability of banking sector is the comer stone for the growth of the Egyptian macro economy. It functions as intermediary linking surplus and deficit units; facilitate funds for productive purpose and thereby contributes to economic development. The functioning of the banking sector is to be affected by many variables like corporate governance, audit quality, and Voluntary disclosure. The stockholders of the listed banks in the stock exchange market are keen to know all the information related to these variables (Alkassim, F. A. 2005).

The Central Bank of Egypt had not issued a new banking license since 1979. The only way for a new commercial foreign or domestic bank to enter the market (with exception for representative offices) is to acquire an existing bank. For example, in 2013, QNB Group purchased National Société Générate Bank-Egypt (NSGB). In the same year, Dubai's largest bank Emirates NBD, acquired BNP Paribas Egypt. The three remaining state-owned banks now in Egypt are National Bank of Egypt, Banque du Caire, and Banque Misr. The three state-owned banks 
control nearly 40 percent of banking sector deposits and loans(CBE Annual report 2014).

The banks in the Egyptian macro economy can be classified into investment banks, commercial banks and specialized banks. Other classification can also, be used, like the non-Islamic banks and the Islamic banks. Non-Islamic banks provide services that are interest based, and on the other hand Islamic banking provides services that are interest-free and based on sharing profit-loss and risk with the client, and using tools like Mudarabah, and Murabha contracts. So, from other point of view non-Islamic banks using interest based approach while Islamic banks using an equity approach. Islamic banking to be considered as an alternate to the non-Islamic banking (Alkassim, F. A. 2005).

Although the similarities and differences between Non-Islamic Banking and Islamic Banking, both exist and compete in the same and must exercise a proper risk management mechanism to moderate the risks faced in the business. Many studies had been conducted regarding the Non-Islamic and the Islamic Banking (Awan, 2009). Many of these previous studies stressed only on comparing between the different types of services and products provided by the two types of banking and the effect on their financial performance. (Hanif, M., 2014).

Mohamed El-Beltagy the Head of the Egyptian Islamic Finance Association (EIFA) declared that clients of the Islamic banks in Egypt estimated to be nearly 2.5 million, representing nearly $20 \%$ of the total clients of the Egyptian banks. The trending popularity of Islamic banking encouraged some of the local and global non-Islamic commercial banks into establishing branches that provide Islamic banking products and services to attract more customers, for example, banks as United Bank, Banque Misr, National Bank of Egypt (NBE), Audi Bank, Social Nasser Bank, Arab Investment Bank (AIB), and others (CBE Annual report 2014).

Corporate governance mechanisms in banking sector are unique in comparison with those applied in other institutions or sectors. They are simply designed to save the interests of shareholders and control the activities of the managers (Jensen and Meckling, 1976). The uniqueness of the banking sector is creating a responsibility of managers to safeguard and manage the resources and funds of investors. Due to the great impact of the banking sector activities on the economic condition of countries, bank acts as a major source of finance for companies and individuals (Shleifer and Vishny, 1997). 


\section{The Egyptian Banking System: regulation and supervision}

Central bank of Egypt (CBE) is considered as the bank of banks and considered as the bank of government bank due to its essential role in supporting the macro economy and executing the physical and monetary policies. One of the main roles of the central banks is to perform supervision and surveillance on the information disclosure of the banking system in Egypt. CBE is performing on-site inspection includes going to the banks locations to review financial performance and check on the management policies applied on locations and also, doing off-site inspections that involves analysis and assessment of bank performance using' financial ratios applied by different types of banking institutions. These ratios to be called a screening ratios that is used to check primarily on financial soundness of banks like liquidity, profitability, capital adequacy and debt ratios. Using these two types of inspections the CBE are keeping an up to date information about the developments happening in the banking industry (Soliman, M.M., 2013).

The auditing of the banks financial statements is required to be done by two external auditors. These auditors must be registered in the central bank and they should provide a report about any misstatement or violation to banking regulations and report on the efficiency of the bank's internal control system. The audit also, done to indicate the techniques used by management for appraising asset quality and management (Abdel Shahid, S.F., 2001).

In case of the public (state-owned) banks, one of the auditors must be the Central Audit Organization (COA) in addition to the external auditor. On the market transparency front, public disclosure of financial information was generally poor. After 1992, Egyptian banks started to pay more attention to the information disclosure and especially the timing for issuing the financial stalemates along with detailed footnotes explaining these financial statements (CBE Annual report, 2010).

The law 95/1992, (capital market law), obligated the listed institutions in the stock market to provide quarterly financial stalemates to the capital market authority, in order to provide information to interested parties, which allowed a more frequent and easy access to information by users of the financial statements.

The next step was in 1997 where the CBE obligated all the banks to prepare their financial statements in accordance to International Accounting Standards (IAS) along with more frequent transparency and disclosure to improve the transparency of the banks. In addition, the uniform accounting and auditing standards beside the application of IAS were necessary to enhance the quality of disclosure and to improve the application of the corporate governance in banks. In 1998, the banks started to issue quarterly financial statements and to publish them in the newspapers along with end of the year financial statement to be issued at the 
end of the year with the previous three quarters to be briefed (Samaha, K., \& Dahawy, K., 2011).

Transparency and disclosure of public banks information have been emphasized mainly for the purposes of accountability and enforcement. The CBE required a monthly financial statements from banks, which needed more close supervision and additional information about non-performing loans, risk-weighted capitalization, and other essential information. These steps allow the CBE to effectively monitor bank behavior and save interest of stakeholders and establish market discipline (Soliman, M.M., 2013).

Also, in order for the CBE to properly discipline the banking sector, bank regulations should be applied forcefully. On-site and off-site supervision should be strengthened to send a strong signal to banks which do not follow prudent practices and to improve solvency of the banking system. A tough stance should be taken when dealing with problem banks such that only those assessed to be viable in the longer term would be restructured but under new management and ownership; bad management should not be rewarded and corporate governance in the banks should be improved (Claessens, S., \& Laeven, L., 2005).

\section{Corporate governance Disclosure in Egypt:}

From agency theory perspective, one of the key factors explaining the decision of non-voluntary and voluntary disclosure is the corporate governance mechanisms. Limited number of researches, which tried to examine relation . between the corporate governance and the disclosure of the corporate governance in banks. Up to the best knowledge of the researcher, five published researches only examined this issue (two of these researches tested that in developed countries, and the other three tested that in developing countries) but the five researches did not examine that in the field of banks (Samaha, K., \& Dahawy, .K., 2011).

In the developed countries, Bujaki and McConomy (2002) conducted their research applying on the Canadian firms: The main result of the research was that voluntary disclosure of corporate governance information to be exercised by firms with unrelated directors. Another research that have been conducted on a sample of European companies, Bauwhede and Willekens (2008) reached that level of corporate governance disclosures is affected by the ownership structure.

In the developing countries, Muhamad, Shahimi, Yahya, and Mahzan (2009) applied their research in Malaysia to reach a conclusion that level of corporate governance disclosure is not affected by corporate governance mechanisms, while in the research of Al- Moataz and Hussainey (2012) applied in saudia arabia that the key incentives for corporate governance disclosures are audit committee size and board independence. Another research conducted by Samaha \& Dahawy 
(2010) applied in Egypt concluded that board independence has a significant impact on the level of corporate governance disclosure.

The CBE define the corporate governance as "a combination of processes and the structure implemented by the board to inform, direct, manage, and monitor the activities of the Central Bank of Egypt (CBE) towards the achievement of its objectives."(CBE, 2015). The governance and accountability framework issued by CBE through Law No. 88 of the 2003 CBE Act that modified by law No. 125 of 2011. In 2012, the Egyptian stock Exchange updated its listing rules issued in 2012 that required all listed institutions to disclose certain non-financial and financial information on the website of the institutions in Arabic.

Corporate governance is to be seen as the guidelines followed by institutions to enable shareholders keeping control over management to act in shareholders' interests and to maximizes institutions efficiency (Blair, M., 1995). This can mean that better corporate governance, by itself, can make banks safer but actually the opposite can happen in sense of giving shareholders more control might make banks more riskier. For example, according to Laeven and Levine (2009), higher shareholder power in the institution can increase the risk of the bank and that banks that have more independent directors on boards suffered higher losses during the economic crisis (Aebi, et. al 2012).

In addition to the corporate governance code, the Basel Committee provided a framework that banks must follow to enhance efficiency and effectiveness of operations and to improve the risk management transparency for decision-making. This framework is to promote public confidence and safety of the banking system (Aebi, et. al 2012).

In the banking industry, there is no single approach for good corporate governance. Although corporate governance has a higher level of significance because banks depend on public trust control public saving, and have a diverse stakeholders. During crisis, the banks with weak corporate governance resulted in the collapse of banks that affects the macro economy as a whole. A greater attention should be placed on Islamic banks because they are exposed more to non-compliance risks, in addition to weaker institutional environments of emerging markets in which they mostly operate (Claessens, 2006). In Islamic banks, depositors participate in the profit and loss like shareholders that makes good governance mechanisms highly required to protect their interest. Because of the diverse stakeholders of banks, a more corporate governance disclosure need to be disseminated in annual reports and corporate reports. (Samaha, et al. 2012)

The ministry of investment with cooperation with the Egyptian Institute of Directors (EIoD) presented the corporate governance code in 2005 for companies that are listed and actively traded in the stock market. In order to enhance the 
confidence level of foreign investors in the Egyptian capital market, the Egyptian Corporate Governance Code (ECGC) was prepared and presented in accordance with the Guidelines on Corporate Governance of State-Owned Enterprises in the Organization for Economic Cooperation and Development (OECD) (Hassan et al., 2006).

This code included many provisions, with the objective to safeguard the rights of shareholders as in addition to various stakeholders. One of the main objectives for issuing that code was to enhance the level of corporate disclosure because transparency to be considered one of the pillars of corporate governance (AbdElsalam and Weetman, 2007). The code was also, presented to provide more accuracy of disclosed corporate information and to organize the relationship between the management, shareholders, and board of directors. This code have been updated again in 2011 and banks started to apply the modified code starting from 2012.

Bushman and Smith (2003) defined corporate governance disclosure and transparency as "the widespread availability of relevant, reliable information about the periodic performance, financial position, investment opportunities, governance, value and risk of publicly traded firms". The knowledge on a bank's governance structure is useful to assess the creditability and reliability of financial information, and to help users to have an accurate assessment and expectations concerning the performance of the bank. These types of disclosure give clear view about the responsibilities of the management in running the institution, how financial resources are invested (Bushman et al., 2004).

Additionally, corporate governance disclosures can enhance maintaining and improving the internal control system, and improve firm performance (Labelle, 2002). In banking sector, due to its unique and highly regulated environment, corporate governance is regulated by banking authority or central banks according to the case. Therefore, corporate governance disclosures about structure and mechanisms of the bank play an essential role in achieving the purpose of comparison to other sectors. (Association of Chartered Certified Accountants, 2009)

\section{Audit quality:}

Financial reporting is an integral part of the financial system by providing reliable and relevant information about the economic performance of the business. Effective financial reporting is based on faithful application of high quality accounting standards and hiring of experienced and independent auditor. Financial reporting is essential to all financial market participants especially investors and creditors in relation to their resource allocation decisions. The trust of all these users in the integrity and transparency of financial reporting is 
essential to sound economic growth and global financial stability (DeZoort, \& Salterio, 2001).

Audit service is essential for increasing the trust of the financial statements users in the financial reports in order to ensure the submission of reliable information that can help users in taking decisions. However, across the time some scandals had impaired the trust of the users in the auditing process by external auditors. For example, in 2001 and 2002 Enron Corporation and Word Com a two USA companies that faced a Hugh scandal in relation to their external auditors; and between 2001 and 2008 the scandal of Bank of Century in Indonesia (Elbannan, M. A., \& Elbannan, M. A. 2015).

By considering these scandals above and other scandals in other places, it was very important to think about improving the audit quality by enhancing the factors that affect audit quality. Therefore, in order to increase the audit quality, auditors should maintain and enhance competency, independence, and accountability in conducting their audit engagement. To ensure the integrity of financial statements the institution must hire an independent external auditor as he provides the necessary assurance for the financial statements reliability (Mehran, et al, 2011).

The auditor must maintain quality in accordance with the auditing standards in accumulating and evaluating sufficient competent evidences that can enable himlher to give the right audit opinion (report) based on his her professional judgment. Therefore, the purpose of an audit activity needs sufficient competent evidences so that it can run successfully (Armstrong, et al, 2015).

Audit quality enhance the quality of financial reporting by raising the level of credibility of the financial statements. This why audit quality is to be considered as one of the components of the financial reporting quality. Actually, it is not that easy to define the financial reporting quality and by default, it is difficult to define the exact nature of the audit quality (Bédard, \& Gendron, 2010).

Previous researches, defined the audit quality as "the probability that auditor can find and report the existence of violation in the client accounting system". The audit quality is the measure that will determine the degree at which users of the financial statements will rely on the information in these financial statements. Due to the importance of the audit quality to the capital markets stability, a large body of researches tried to investigate the audit quality definition and measurement (Bedard, et al, 2010; DeFond and Zhang 2014).

The ability to define and measure the audit quality enables the users of the financial statements to assess the improvement of the audit quality over time, while also encourage audit firms to improve their audit quality. The oversight boards are also, a key player for supervising the audit quality of audits through 
inspection reports and other releases, for instance the PCAOB releases that provide audit committee members some instruction regarding issues to be discussed with auditors (Ragothaman, et al, 2014).

The PCAOB has launched its own project to define and measure audit quality in order to provide additional information about audit quality and the audit process. The researcher used this project details for understanding the audit quality attributes and getting many of the audit quality indicators (Ragothaman, et al, 2014).

The audit professionals defined audit quality in terms of compliance with auditing standards, while investors depend more on the individual characteristics of the audit team performing the audit. Investors' emphasized on the auditor characteristics that suggests that additional input-related disclosures in the financial statements can be useful to the users in evaluating audit quality. In terms of audit-specific characteristics of audit quality, both, investors and audit professionals consider the characteristics of the audit fees, timely completion of audit, no. of lawsuits, audit risk, and type of audit report as a measurement criteria for audit quality (DeFond and Zhang 2014).

There was almost an agreement on the effect of individual auditor characteristics on the audit quality. In addition, some researches supported that input from parties outside the core engagement team like client-specific experts and engagement review partners is an important contributors to the audit quality. However, investors' perceptions of audit quality did not take into consideration the role of the audit committee in enhancing the audit quality and ensuring the support for making this information about audit quality more transparent to users (Calabrese, et al 2013).

Finally, Prior researches used a variety of proxies for audit quality, including lawsuits filed against auditors, audit fees, going concern opinions, and client bankruptcies (Francis and Michas 2012). The variety of proxies used to measure audit quality indicated a diversity of views among researchers regarding a reliable measure of audit quality and indicated that these proxies are not adequate to represent the construct of audit quality. (Dichev, et al 2013).

KPMG had proposed an audit quality framework that included components consistent with the previous literature review the researcher reclassified the audit quality disclosure measurement constructs into two main categories the auditing firm determinants and the audit process determinants. Each of the two categories show the information that should be disclosed within the financial statements or within the information disclosed by the auditor about himself in order to enhance the financial performance of the institutions being audited (Christensen, et al 2013). 


\section{Voluntary disclosure:}

Many previous researches had examined the voluntary disclosure. The main objective of these researches were to examine the level of voluntary disclosure and its relation with different firm characteristics to explain the variation among investigated companies in developing and developed countries (Elbannan, M. A., \& Elbannan, M. A. 2015).

Firth (1979) examined the relationship between the level of voluntary disclosure in the annual reports of 180 British companies with auditor type and firm size. The paper used a disclosure index included 48 information variables. The research results showed a positive relationship between the level of voluntary disclosure and the firm size and non-significant relation with auditor type.

Cooke (1989) used data of 90 non-financial Sweden companies to test the corporate voluntary disclosure. This research concluded that voluntary disclosure is positively related to firm size. Another conclusion was that level of disclosure in trading firms is higher than service and manufacturing firms.

In 1991, Cooke repeated the research on the annual reports of Japanese firms and he examined the relation between the level of voluntary disclosure and firm size, listing status and industry type. Unlike Swedish manufacturing companies, Japanese manufacturing companies were to disclose more information voluntarily than trading and services companies (Cooke, 1991).

In Switzerland, Raffournier (1995), an index have been made out of 30 voluntary financial disclosure items used to investigate the level of disclosure in listed companies. The research examined the relation between firm characteristics, profitability leverage, size, audit firm, fixed assets, and ownership structure and voluntary disclosure.

Gruning (2007) illustrated that the corporate disclosure attributes are various and a good research of the all-surrounding factors is needed trying to understand the interrelated impact of these attributes. The research have been applied using annual financial statements of German and Poland companies, to investigate interrelations between attributes of corporate disclosure like cross listing firm size, and type of industry. Firm size has an indirect effect on the attributes of corporate disclosure, and cross listing status found to have a direct impact on the attributes of corporate disclosure.

Many other researchers examined the relation between the voluntary and non-voluntary disclosure attributes. Abayo et al. (1993) examined the quality of financial disclosure in the annual financial statements of companies in Tanzania. The attributes used to examine the quality of disclosure included voluntary 
disclosure, compliance with non-voluntary disclosure requirements, the audit report type, and information timeliness. The results of the research stated poor quality of voluntary and non-voluntary disclosure attributes in the Tanzanian companies. The research stated also, the weak relation between voluntary and non-voluntary disclosure (Abayo et al., 1993).

Hossain, et al. (1994) examined the relation between the firm characteristics gearing, firm size, ownership structure, audit firm and listing status in Malaysian companies. The research included a checklist of 78 variables to measure the voluntary disclosure level in listed companies for the year 1991 on the Kuala Lumpur Stock Exchange. The findings of the research illustrated that there is a significant relation between audit firm, ownership structure and firm size with the level of voluntary disclosure.

Al-Razeen and Karbhari (2004) examined the relation between the voluntary and non-voluntary disclosures in annual financial reports in Saudi Arabia. The research classified the attributes of disclosure into three types: 23 non-voluntary, and 15 voluntary variables. The research results showed the insignificant relation between board of directors and the management in disclosing information in the annual report.

Alsaeed (2006) examined the level of disclosure in the annual financial reports in Saudi Arabian companies and tested statistically the relation between firm characteristics like ownership dispersion, debt ratio, firm size, profit margin, and others and the level of disclosure. The researcher used a checklist of 20 attributes of voluntary disclosure variables in the annual financial reports for the year 2003. The research results emphasized on the significant positive reaction between the firm size and the level of voluntary disclosure and the insignificant relation with the other firm characteristics.

Aljifri (2008) investigated the level of the voluntary and non-voluntary disclosure in the annual financial reports of 31 companies in the United Arab Emirates (UAE). The researcher used an index of 73 disclosure attributes to assess the significance of the relation between the level of disclosure and the type of the company sector. The research results illustrated a significant relation between the level of disclosure and the sector type (industrial, insurance, banks and service). The research stated that banking sector is the one that have the higher level of disclosure among all the other sectors and this was due to the strict control of the Central bank. The weak oversight board legal and institutional control were the reasons for the weak disclosures among the other sectors (Mehran, et al. 2011). 


\section{Prior disclosure studies within the Egyptian context}

Egypt as an emerging capital market was in need for more attention toward corporate governance, and transparency, although the international published research on disclosure attributes of listed companies in Egypt is still limited. However, many studies examined the disclosure attributes within the Egyptian context. There were studies emphasized on the disclosure attributes of non-voluntary disclosure (Abd-Elsalam and Weetman 2007, and Dahawy et al 2002) and other studies that emphasized on the voluntary disclosure (Hassan et al 2006, and Rizk et al 2008).

Abd-Elsalam and Weetman (2007) examined the attributes of non-voluntary disclosure in 20 Egyptian companies' annual financial reports for year's 1991/92 and 72 companies for years 1995/96 to investigate the effect of regulatory changes (capital market law no. 95/1992) on the level of non-voluntary disclosure. The researcher used a checklist of 241 non- voluntary attributes to test the level of compliance with disclosure requirements. The results of the research was that when introducing a new regulation a case of unfamiliarity of that law may lead to noncompliance by the companies.

Dahawy et al., (2002) examined the difference between the disclosure requirements of the standard and the secretive nature of the culture in Egypt. The research included a deep analysis of the disclosure attributes of the 3 newly privatized companies in Egypt for three years ( 2 years prior to privatization and 1 year after). The three companies were operating in the same sector, which is the infrastructure sector. The results of the research emphasized that level of disclosure in the annual financial reports is lower than the requirements of the international accounting standards and that there is a significant relation between the Egyptian culture factors and the IAS implementation.

Hassan et al., (2006) examined the level of disclosure over listed companies in the Egyptian stock exchange over the years 1995 to 2002. The research examined both the voluntary and the non-voluntary disclosure attributes. The research indicated that level of has increased dramatically over the research period. The research examined the non-voluntary items of information that varied over time in disclosure until they became at end a voluntary disclosure. However, the research result stated that the lower compliance ratio of non-voluntary disclosure does not change the obligatory nature of this disclosure.

Rizk et al (2008) examined for the first time the corporate social responsibility .disclosure as an item of the voluntary disclosure attributes in the Egyptian capital market. The sample emphasized in the empirical investigation of the research on the company's legal form and not the ownership percentages and the research did not explain the reasons beyond the disclosure of some firm characteristics and 
corporate governance rules.

Based on the literature review and interviews made by the researcher with experts from the EIBD and the Big 4 auditing firms that have offices in Egypt, the researcher reached to the attributes that are presented in the next section of the research.

\section{The constructs of disclosure attributes:}

Figure (1) representing the main constructs presented by the research to measure the three main variables of the model (independent variables) Corporate governance disclosure, audit quality disclosure, and the voluntary disclosure and their effect on the financial performance of the banking sector(dependent variable).

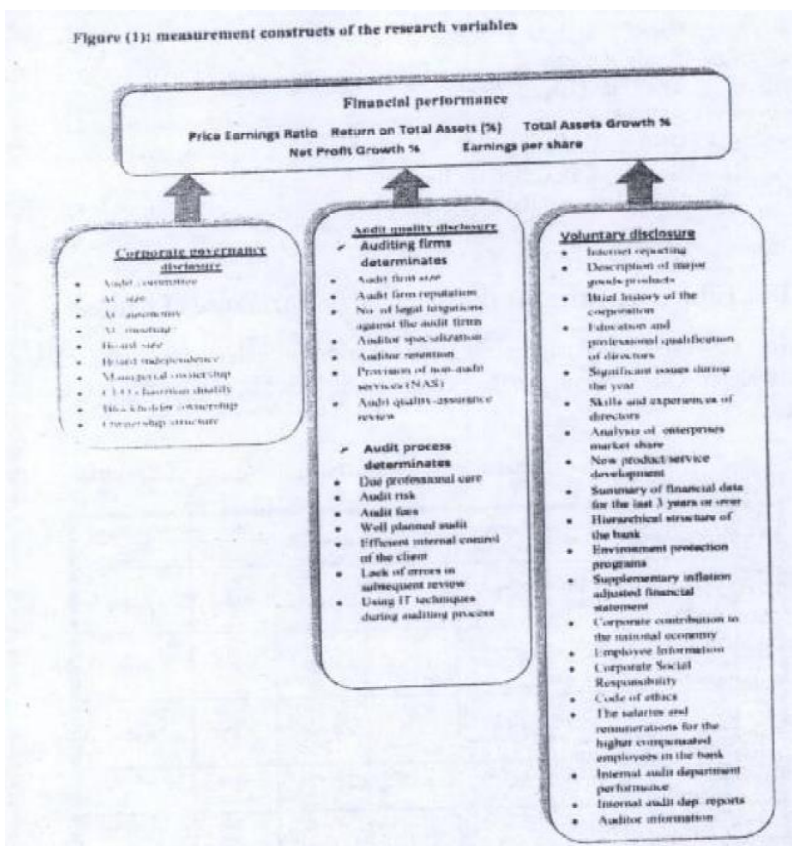

\section{Statistical analysis:}

Based on sample of 12 banks (3 Islamic and 9 non-Islamic banks) that are listed in the Egyptian exchange market. The researcher used the annual reports and the disclosure books of the selected banks listed in the stock market over the period 2004 up to 2014. The following is the Banks listed in the stock exchange market and used as a sample in the research:

\section{Commercial International Bank (Egypt)}




\section{Egyptian Gulf Bank}

3. Faisal Islamic Bank of Egypt

4. Export development bank of Egypt

5. Societe Arabe Internationale De Banque (SAIB)

6. Suez Canal Bank

7. Credit Agricole

8. Abu Dhabi Islamic Bank

9. Al Baraka Bank

10.QNB AL Ahli

11. Housing \& Development Bank

12. Union National Bank

Descriptive statistics for the financial performance of banks:

The researcher carried out descriptive statistics that includes means, standard deviation, standard error, and the measures of distribution, as shown below in table (1):

Table (1): Descriptive statistics Tor the financial performance of Egyptian banks

\begin{tabular}{|c|c|c|c|c|c|c|c|}
\hline \multirow{2}{*}{ Na. } & \multirow{2}{*}{ Companies } & \multirow{2}{*}{ Mean } & \multirow{2}{*}{$\begin{array}{l}\text { Standard } \\
\text { devlatlon }\end{array}$} & \multirow{2}{*}{$\begin{array}{c}\text { Standard } \\
\text { error }\end{array}$} & \multirow{2}{*}{ Howvass } & \multicolumn{2}{|c|}{ Kolmegorov-8mirnav } \\
\hline & & & & & & stuthatle & Sig. \\
\hline I & $\begin{array}{l}\text { Prite } \\
\text { Rarnings } \\
\text { Rafle } \\
\end{array}$ & 13.479 & 0.9733 & 0.6116 & 0.214 & 0.004 & 0.200 \\
\hline 2 & $\begin{array}{l}\text { Return aa } \\
\text { Totai } \\
\text { Asseis (\%) }\end{array}$ & 1.4541 & 0.8525 & 0.0747 & 0.305 & 0.115 & 0.801\%w \\
\hline 3 & $\begin{array}{l}\text { Total } \\
\text { Assets } \\
\text { Growth \% }\end{array}$ & $\begin{array}{c}11.228 \\
8\end{array}$ & 5.4291 & 0.4701 & -0.008 & 0.073 & $0.08 \mathrm{sh}$ \\
\hline 4 & $\begin{array}{l}\text { Net Profit } \\
\text { Growth \% }\end{array}$ & 12.92 & 13.551 & 1.188 & 0.490 & 0.110 & $0.001 \times 2 \pi$ \\
\hline 5 & $\begin{array}{l}\text { Earaings } \\
\text { Fer Share }\end{array}$ & 0.743 & 0.5141 & 0.0451 & 0.492 & 0.102 & $0.002 \times$ \\
\hline
\end{tabular}


*** Parameter is significant at the (.001) level.

** parameter is significant at the (.005) level.

According to Descriptive statistics in table (1), can conclude that:

- The Price Earnings Ratio mean value is (13.479), with skewness coefficient (0.214) tends to left, which indicates normality distribution of $\mathrm{P}(\mathrm{E}$ values, since the significant of Kolmogorov-Smirnov statistic greater than (0.05).

- The Return on Total Assets (\%) mean value is $(1,4541)$, with skewness coefficient $(0,305)$ tends to right, which indicates non-normality distribution of Return on Total Assets (\%), since the significant of Kolmogorov-Smirnov statistic less than $(0,05)$.

- The Total Assets Growth (\%) mean value is (11.2288), with skewness coefficient (-0.068) tends to right, which indicates non-normality distribution of Total Assets Growth (\%) since the significant of Kolmogorov-Smirnov statistic greater than $(0,05)$.

- The Net Profit Growth (\%) mean value is (12.92), with skewness coefficient (0.496) tends to right, which indicates non-normality distribution of Total Assets Growth (\%) since the significant of Kolmogorov-Smirnov statistic less than $(0.05)$.

- The EPS mean value is (0.743), with skewness coefficient (0.492) tends to right, which Indicates non-normality distribution of EPS since the significant of Kolmogorov-Smirnov statistic less than (0.05).

The researcher can conclude that the descriptive statistics, Kolmogorov-Smirnov test and skewness results indicated the significance of the Return on Total Assets $(\%)$, Net Profit Growth \%, and EPS as indicators for the performance of die Egyptian banks (Islamic and non-Islamic) listed in the stock exchange marker with significant greater than 0.05 .

Table (2): Descriptive statistics for the corporate governance disclosure attributes:

\begin{tabular}{|c|c|c|c|}
\hline variables & & Erequenc & Percentage \\
\hline \multirow{5}{*}{ 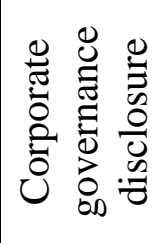 } & Audit committee & 104 & $80 \%$ \\
\hline & Audit committee size & 81 & 62.3 \\
\hline & AC autonomy & 80 & 61.50 \\
\hline & AC meetings & 51 & 39.2 \\
\hline & Board size & 80 & 61.5 \\
\hline
\end{tabular}




\begin{tabular}{|c|c|c|c|}
\hline \multirow{4}{*}{} & Board independence & 80 & 61.50 \\
\cline { 2 - 4 } & $\begin{array}{c}\text { Managerial } \\
\text { ownership }\end{array}$ & 86 & 66.2 \\
\hline $\begin{array}{c}\text { CEO-chairman } \\
\text { duality }\end{array}$ & 68 & 52.30 \\
\cline { 2 - 4 } & $\begin{array}{c}\text { Blockholder } \\
\text { ownership }\end{array}$ & 78 & 60 \\
\cline { 2 - 4 } Ownership structure & 87 & 66.9 \\
\hline
\end{tabular}

Table (2) shows the frequency of corporate governance disclosure within the sample of the listed banks in the Egyptian stock exchange market. The results indicate that the audit committee, and Ownership structure with percentage of $80 \%$ and $66,90 \%$ respectively are the highest among the other corporate governance disclosure attributes.

Table (3): Descriptive statistics for the Audit quality disclosure attributes:

\begin{tabular}{|c|c|c|c|}
\hline Variables & & Frequency & Percentage \\
\hline \multicolumn{4}{|c|}{ Audit quality } \\
\hline \multirow{6}{*}{ 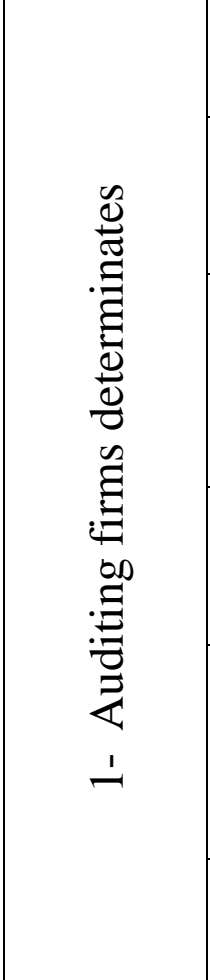 } & - Audit firm size & 3 & $2.30 \%$ \\
\hline & - Audit firm reputation & 9 & 6.9 \\
\hline & $\begin{array}{c}\text { No. of legal litigations against the } \\
\text { audit firms }\end{array}$ & 3 & 2.30 \\
\hline & - Auditor specialization & 1 & 0.80 \\
\hline & $\begin{array}{c}\text { - Provision of non-audit services } \\
\text { (NAS) }\end{array}$ & 60 & 46.2 \\
\hline & - Audit quality-assurance review & 33 & 25.4 \\
\hline 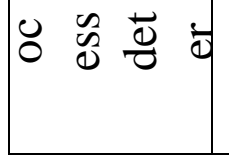 & $\begin{array}{l}\text { - The audit team exercised due } \\
\text { professional care throughout the }\end{array}$ & 2 & 1.5 \\
\hline
\end{tabular}




\begin{tabular}{|c|c|c|c|}
\hline Variables & & Frequency & Percentage \\
\hline & conduct of the audit engagement & & \\
\hline & - Audit risk & 2 & 1.5 \\
\hline & - Audit fees & 2 & 1.5 \\
\hline & - Well planned audit & 2 & 1.5 \\
\hline & $\begin{array}{c}\text { - Efficient internal control of the } \\
\text { client }\end{array}$ & 70 & 53.8 \\
\hline & $\begin{array}{c}\text { - Lack of errors in subsequent } \\
\text { review }\end{array}$ & 6 & 4.6 \\
\hline & $\begin{array}{c}\text { - Using IT techniques during } \\
\text { auditing process }\end{array}$ & 0 & 0 \\
\hline
\end{tabular}

Table (3) shows audit quality disclosure attributes that include auditing firm determination which include the Provision of non-audit services (NAS) with a percentage of $45.20 \%$, and audit process determines which include Efficient internal control of the client with a percentage of $53.8 \%$.

Table (4): Descriptive statistics for the Voluntary disclosure attributes:

\begin{tabular}{|c|c|c|c|}
\hline Variables & & Frequency & Percentage \\
\hline \multirow{6}{*}{ 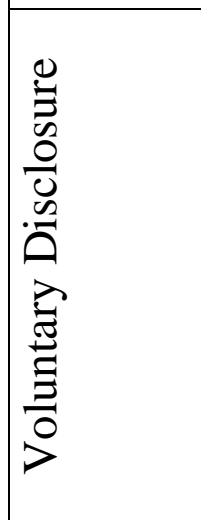 } & -Internet reporting & 123 & $94.6 \%$ \\
\hline & $\begin{array}{l}\text {-Description of major } \\
\text { goods/products }\end{array}$ & 130 & 100 \\
\hline & - Brief history of the bank & 49 & 37.7 \\
\hline & $\begin{array}{l}\text {-Education and professional } \\
\text { qualification of directors }\end{array}$ & 0 & 0 \\
\hline & $\begin{array}{l}\text {-Significant issues during the } \\
\text { year }\end{array}$ & 130 & 100 \\
\hline & -Skills and experiences of & 71 & 54.6 \\
\hline
\end{tabular}




\begin{tabular}{|l|l|c|c|}
\hline Variables & Frequency & Percentage \\
\hline $\begin{array}{l}\text { directors } \\
\text {-Analysis of enterprises' } \\
\text { market share }\end{array}$ & 21 & 16.20 \\
\hline $\begin{array}{l}\text {-New product/service } \\
\text { development }\end{array}$ & 78 & 60 \\
\hline $\begin{array}{l}\text { - Summary of financial data } \\
\text { for the last 3 years or over }\end{array}$ & 25 & 19.20 \\
\hline $\begin{array}{l}\text {-hierarchical structure of the } \\
\text { bank }\end{array}$ & 16 & 12.30 \\
\hline $\begin{array}{l}\text {-Environment protection } \\
\text { programs }\end{array}$ & 71 & 54.60 \\
\hline $\begin{array}{l}\text {-supplementary inflation } \\
\text { adjusted financial statement }\end{array}$ & 7 & 5.40 \\
\hline $\begin{array}{l}\text {-Corporate contribution to the } \\
\text { national macro economy }\end{array}$ & 74 & 56.90 \\
\hline $\begin{array}{l}\text {-Employee Information } \\
\text {-Corporate Social } \\
\text { Responsibility }\end{array}$ & 81 & 62.30 \\
\hline $\begin{array}{l}\text {-Code of ethics } \\
\text { - The salaries and } \\
\text { remunerations for the higher } \\
\text { compensated employees in } \\
\text { the bank }\end{array}$ & 12 & 45.2 \\
\hline $\begin{array}{l}- \text { Internal audit department } \\
\text { performance }\end{array}$ & 10 & 7.71 \\
\hline $\begin{array}{l}\text { - Internal audit dep. reports } \\
\text { - Auditor information }\end{array}$ & 0 & 0 \\
\hline
\end{tabular}

Table (4) shows the frequency and percentage of the measurement constructs within the voluntary disclosure attributes in the listed banks in the stock exchange market. The table indicated that the highest percentage of disclosure within the voluntary disclosure attributes is the Description of major goods/products with percentage of $100 \%$, then come the Internet reporting with percentage of $94.60 \%$ out of the sample of listed banks. In addition, the table indicates that some of the attributes have not been ever reported in the sample selected like the Education and professional qualification of directors and internal audit dep. reports with zero $\%$ of disclosure. 
Table (5): Descriptive statistics for the independent variables:

\begin{tabular}{|c|c|c|c|}
\hline Variables & Mean & Std & SE \\
\hline $\begin{array}{c}\text { - Corporate } \\
\text { governance }\end{array}$ & -0.6115 & -0.1654 & -0.01451 \\
\hline -Audit quality & -0.107 & -0.0975 & -0.6686 \\
\hline -Voluntary disclosure & -0.514 & -0.0960 & -0.008 \\
\hline
\end{tabular}

Table (5) shows the descriptive analysis results for the independent analysis. The results indicated that the corporate governance came in the first place of disclosures to be presented by the banks listed in the stock exchange market and the researcher could justify that for the obligation imposed by the central bank of Egypt and the Egyptian financial supervisory authority for financial reporting and listing requirements in die stock exchange market. Then come the voluntary disclosure attributes in the second place with a mean of 0.514 , and in the last with very low mean value the audit quality disclosure attributes.

Table (6): 1-test to measure the significant differences between performance measures for Islamic and nun-Islamic banks:

\begin{tabular}{|c|c|c|c|c|c|c|c|}
\hline No. & & $\begin{array}{c}\text { Type of } \\
\text { Bank }\end{array}$ & Mean & Std & SE & $\begin{array}{c}\text { t- } \\
\text { Value } \\
\end{array}$ & Sig. \\
\hline \multirow[t]{2}{*}{1} & \multirow{2}{*}{$\begin{array}{c}\text { Price Earnings } \\
\text { Ratio }\end{array}$} & $\begin{array}{l}\text { Non- } \\
\text { Islamic }\end{array}$ & 14.205 & 7.0557 & 0.7164 & \multirow{2}{*}{2.061} & \multirow{2}{*}{$0.041^{*}$} \\
\hline & & Islamic & 11.345 & 6.3548 & 1.1062 & & \\
\hline \multirow[t]{2}{*}{2} & \multirow{2}{*}{$\begin{array}{c}\text { Return on Total } \\
\text { Assets } \%\end{array}$} & $\begin{array}{l}\text { Non- } \\
\text { Islamic }\end{array}$ & 5549 & 0.90997 & 0.09239 & \multirow[t]{2}{*}{2,350} & \multirow[t]{2}{*}{$0,020-$} \\
\hline & & Islamic & 1.1500 & 0.56991 & 0.9921 & & \\
\hline \multirow[t]{2}{*}{3} & \multirow{2}{*}{$\begin{array}{c}\text { Total Assets } \\
\text { Growth } \%\end{array}$} & $\begin{array}{l}\text { Non- } \\
\text { Islamic }\end{array}$ & 10.8674 & 5.76561 & 0.58541 & \multirow[t]{2}{*}{-1.305} & \multirow[t]{2}{*}{0.194} \\
\hline & & Islamic & 12.2912 & 4.18757 & 0.72896 & & \\
\hline \multirow[t]{2}{*}{4} & \multirow{2}{*}{$\begin{array}{l}\text { Net Profit } \\
\text { Growth \% }\end{array}$} & $\begin{array}{c}\text { Non- } \\
\text { Islamic }\end{array}$ & 15.78 & 13.914 & 1.413 & \multirow[t]{2}{*}{4.424} & \multirow[t]{2}{*}{$0.001 * *$} \\
\hline & & Islamic & 49 & 7.828 & 1363 & & \\
\hline \multirow{2}{*}{5} & \multirow{2}{*}{$\begin{array}{l}\text { Earnings per } \\
\text { share }\end{array}$} & $\begin{array}{l}\text { Non- } \\
\text { Islamic }\end{array}$ & 0.769 & 0.5362 & 0.0544 & \multirow{2}{*}{1.006} & \multirow{2}{*}{0316} \\
\hline & & Islamic & 0.665 & 0.4410 & 0.0768 & & \\
\hline
\end{tabular}

* parameter is significant at the (.05) level

*** parameter is significant at the (.001) level

Table (6) showing the results of the t-test for the performance measures in Islamic and non-Islamic banks where the significance is less than 0.05 for the price-earnings ratios, return on total assets (\%), and net profit growth (\%). In 
addition, it can be concluded that all the measures are significant more in favor of measuring the performance of the non-Islamic banks versus the Islamic banks except for Total Assets Growth \%. The researcher can conclude that the there is a significant difference between the Islamic and the non-Islamic banks regarding the financial performance indicators presented by the researcher.

\section{Table (7): t-test to measure the significant differences between disclosures} attributes for Islamic and non-Islamic banks:

\begin{tabular}{|c|c|c|c|c|c|c|c|}
\hline No. & & Type of Bank & Mean & Std & SE & T-Value & Sig. \\
\hline \multirow{2}{*}{1} & \multirow{2}{*}{$\begin{array}{l}\text { Corporate } \\
\text { governance }\end{array}$} & Non-Islamic & 0.6103 & 0.1728 & 0.0175 & \multirow{2}{*}{-0.145} & \multirow{2}{*}{$\begin{array}{c}.885 \text { Non } \\
\text { sig. }\end{array}$} \\
\hline & & Islamic & 0.6152 & 0.14388 & 0.02505 & & \\
\hline \multirow{2}{*}{2} & \multirow{2}{*}{$\begin{array}{l}\text { Audit } \\
\text { quality }\end{array}$} & Non-Islamic & 0.116 & 0.1050 & 0.0107 & \multirow{2}{*}{1.257} & \multirow{2}{*}{$\begin{array}{c}.211 \\
\text { Non sig. }\end{array}$} \\
\hline & & Islamic & 0.089 & 0.0692 & 0.0121 & & \\
\hline \multirow[b]{2}{*}{3} & \multirow{2}{*}{$\begin{array}{l}\text { Voluntary } \\
\text { disclosure }\end{array}$} & Non-Islamic & 0.558 & 0.0998 & 0.0101 & \multirow[b]{2}{*}{2.967} & \multirow[b]{2}{*}{$.003 * * \mathrm{Sig}$} \\
\hline & & Islamic & 0.472 & 0.0698 & 0.0121 & & \\
\hline
\end{tabular}

* parameter is significant at the (.05) level

** parameter is significant at the (.01) level

*** parameter is significant at the (.001) level

According to t-test in table (7), the following can be concluded:

- There are significant differences between Islamic and non-Islamic hanks in relation to disclosure attributes, for example the voluntary disclosure with tlest value (2.967) and at significant level less than (0.05) and the audit quality with l-test value $(1,257)$ and at significant level greater than $(0.05)$

- There is no significance difference between Islamic and non-Islamic banks in relation the disclosure attributes of corporate governance with t-test value $(-0.145)$ and at significant level greater than (0.05). The researcher justifies that due to the obligatory corporate governance guidelines enforced by the Egyptian central bank, which give no space for any differences between the Islamic and the non-Islamic banks, which is not the case in relation to the other disclosure attributes of audit quality and voluntary disclosure. 
Table (8): Pearson correlation matrix to measure a significant linear relationship between the disclosures attributes and the financial performance of banks

\begin{tabular}{|l|c|c|c|c|c|}
\hline \multicolumn{1}{|c|}{ constructs } & P/E & ROTA\% & TAG\% & NPG\% & EPS \\
\hline Corporate governance & $.330^{* * *}$ & $.344^{* * *}$ & $.265^{* *}$ & $.228^{* * *}$ & $.201^{*}$ \\
\hline Audit quality & $.575^{* * *}$ & $.466^{* * *}$ & -.001 & $-.244^{* *}$ & $-.328^{* * *}$ \\
\hline Voluntary disclosure & $.242^{* *}$ & $.323^{* * *}$ & $.440^{* * *}$ & $.360^{* * *}$ & $.348^{* * *}$ \\
\hline
\end{tabular}

* Parameter is significant at the (.05) level

** Parameter is significant at the (-01) level

***Parameter is significant at the (.001) level

1. According to Pearson correlation matrix, There are significant positive linear relationships between the disclosure attributes of corporate governance, voluntary disclosure and the performance measures of banks including price earnings ratio (P/E), Return on Total Assets (ROTA\%), Total Assets Growth $\%$ (TAG\%), and Net Profit Growth \% (NPGG\%) at Significant level less than (0.013 and in relation to Earnings per share (EPS) at Significant level less than (0.05).

2. According to Pearson correlation matrix, There are significant negative linear relationships between the disclosure attributes of audit quality and Net Profit Growth \% (NPGG\%) and Earnings per share (EPS), at Significant greater than $(0.001)$

\section{Multi-group analysis:}

The multi group analysis will illustrate the Regression weights according to Maximum Likelihood Estimates for the two main groups of the research (sample) which are the Islamic and non-Islamic banks listed in the Egyptian exchange market The analysis will help the researcher in designing the regression models for each of the disclosure attributes in relation to the financial performance of the two groups of banks. Table (9) and (10) present the regression weights for the Islamic and non-Islamic banks relating the disclosure attributes and the financial performance. 
Figure (2): Path analysis for the impact of the disclosure attributes on the financial performance of the both groups of banks through using the path analysis technique.

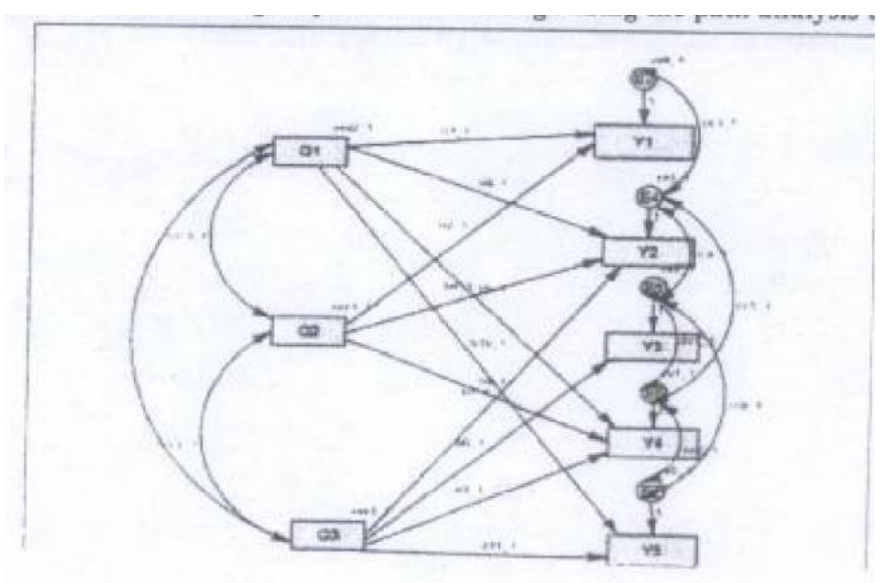

Table (9): Regression weights according to Maximum Likelihood Estimates Tor non-Islamic banks

\begin{tabular}{|c|c|c|c|c|c|c|c|}
\hline \multicolumn{2}{|c|}{ path } & $\begin{array}{c}\text { Standardized } \\
\text { estimate }\end{array}$ & $\begin{array}{c}\text { Unstandardized } \\
\text { estimate }\end{array}$ & S.E. & C.R. & P \\
\hline Y1(P/E) & $<---$ & Q1(CG) & .321 & .475 & .126 & 3.766 & $0.001 * * *$ \\
\hline Y1(P/E) & $<---$ & Q2(AQ) & .505 & .602 & .101 & 5.932 & $0.001 * * *$ \\
\hline Y4 (NPG \%) & $<---$ & Q3(VD) & .445 & .388 & .086 & 4.530 & $0.001 * * *$ \\
\hline Y4 (NPG \%) & $<---$ & Q2(AQ) & -.183 & -.099 & .039 & -2.531 & 0.011 \\
\hline Y4 (NPG \%) & $<---$ & Q1(CG) & -.039 & -.026 & .058 & -.450 & 0.653 \\
\hline Y3 (TAG \%) & $<---$ & Q3(VD) & .427 & .404 & .088 & 4.616 & $0.001 * *$ \\
\hline Y2 (ROTA \%) & $<---~$ & Q3(VD) & .096 & .166 & .105 & 1.576 & 0.115 \\
\hline Y2 (ROTA \%) & $<---$ & Q2(AQ) & .443 & .475 & .088 & 5.429 & $0.001 * * *$ \\
\hline Y2 (ROTA \%) & $<---$ & O1(CG) & .403 & .537 & .114 & 4.694 & $0.001 * * *$ \\
\hline Y5 (EPS) & $<---$ & Q1(CG) & -.009 & -.006 & .065 & -.096 & .924 \\
\hline Y5 (EPS) & $<---$ & Q3(VD) & .360 & .331 & .095 & 3.478 & $0.001 * * *$ \\
\hline
\end{tabular}

* Parameter is significant at the (.05) level

** Parameter is significant at the (.01) level

***Parameter is significant at the (.001) level

1. There are significant positive linear relationships between the disclosure attributes corporate governance, and the audit quality and financial performance measure in term of price earnings ratio at significant level less than (0.001) respectively. This exclude the voluntary disclosure out of the regression model for the price earning measure. The regression model has $\mathrm{R}^{2}=31.80 \%$ to explain the variation to happen in the price earnings ratio, 


$$
Y_{1}=0.321 Q_{1}{ }^{\circ}+0.505 Q_{2}
$$

2. There are significant positive linear relationships between the disclosure attributes corporate governance, and audit quality and financial performance measure in term of Return on Total Assets (\%) at significant level less than (0.001) except for the voluntary disclosure at significant level greater than $(0.05)$. The regression model has $\mathrm{R} 2=36 \%$ to explain the variation to happen in the Return on Total Assets (\%).

$$
Y 2=0.403 Q 1^{\circ}+0.443 Q 2^{\bullet}+0.096 Q 3
$$

3. There are significant positive linear relationships between the disclosure attributes voluntary disclosure and financial performance measure in term of Total Assets Growth \% at significant level less than (0.001). The regression model has $\mathrm{R} 2=18.20 \%$ to explain the variation to happen in the Total Assets Growth \%.

$$
Y 3=0.427 Q 1^{\cdot}
$$

4. There are significant positive linear relationship between the disclosure attribute voluntary disclosure and financial performance measure in term of Met Profit Growth \% at significant level less than (0.001) but negative linear relationship between the disclosures attributes audit quality and financial performance measure in term of Net Profit Growth \% at significant level less than (0.05). The regression model has $\mathrm{R} 2=36 \%$ to explain the variation to happen in the Net Profit Growth \%.

$$
Y 4=-0.039 Q 1-0,183 Q 2 *+0.445 Q 3 *
$$

5. There are significant positive linear relationship between the disclosure attribute voluntary disclosure and financial performance measure in term of Earnings Per Shan: at significant level less than $(0.00 \mathrm{I})$ but negative linear relationship between the disclosure attributes corporate governance and financial performance measure in term of Earnings Per Share at significant level greater than $(0,05)$. The regression model has R2-12.70\% to explain the variation to happen in the Earnings per Share

$$
Y 5=-0.009 Q 1+0.360 Q 3
$$


Table (10): Regression weights according to Maximum Likelihood Estimates for Islamic banks

\begin{tabular}{|c|c|c|c|c|c|c|c|}
\hline \multicolumn{3}{|c|}{ Path } & \multicolumn{2}{|c|}{\begin{tabular}{|c|c} 
Standardize & Unstandardize \\
d. estimate & d. estimate
\end{tabular}} & S.E. & C.R. & \multirow{2}{*}{$\frac{\mathbf{P}}{0.001 * * *}$} \\
\hline $\mathrm{Y} 1(\mathrm{P} / \mathrm{E})$ & $\begin{array}{l}<-- \\
\end{array}$ & $\mathrm{Q} 1(\mathrm{CG})$ & .277 & .354 & .107 & 3.312 & \\
\hline $\mathrm{Y} 1(\mathrm{P} / \mathrm{E})$ & $<--$ & Q2(AQ) & .775 & 1.042 & .112 & 9.272 & $0.001 * * *$ \\
\hline Y4 (NPG \%J & $<--$ & Q3(VD) & .202 & .276 & .230 & 1.197 & .231 \\
\hline Y4 (NPG \%) & $<--$ & Q2(AQ) & -.171 & -.118 & .089 & -1.320 & .187 \\
\hline Y4 (NPG \%) & $<--$ & $\mathrm{Q} 1(\mathrm{CG})$ & .314 & .251 & .098 & 2.553 & $0.11 * *$ \\
\hline Y3 (TAG \%) & $<--$ & Q3(VD) & .493 & .542 & .168 & 3.229 & $.001 * * *$ \\
\hline Y2 (ROTA \%) & $<--$ & Q3(VD) & -.071 & -.134 & .203 & -.661 & .508 \\
\hline Y2 (ROTA \%) & $<--$ & Q2(AQ) & .660 & .629 & .125 & 5.051 & $0.001 * * *$ \\
\hline Y2 (ROTA \%) & $\begin{array}{l}<-- \\
\end{array}$ & $\mathrm{Q} 1(\mathrm{CG})$ & .128 & .116 & .127 & .912 & .362 \\
\hline Y5(EPS) & $<--$ & $\mathrm{Q} 1(\mathrm{CG})$ & .104 & .058 & .101 & .576 & .565 \\
\hline YS(EPS) & $<--$ & Q3(VO) & .246 & .287 & .220 & 1.304 & .192 \\
\hline
\end{tabular}

* parameter is significant at the (.05) level

*** parameter is significant at the (.001) level

1. There are significant positive linear relationships between the disclosure attributes corporate governance, and the audit quality and financial performance measure in term of price earnings ratio at significant level less than (0.001) respectively. This exclude the voluntary disclosure out of the regression model for the price earning measure. The regression model has $(\mathrm{R} 2=78.80 \%)$ to explain the variation to happen in the price earnings ratio.

$$
Y 1=0.277 Q 1 *+0.775 Q 2 *
$$

2. There are significant positive linear relationships between the disclosure attribute audit quality and corporate governance and financial performance measure in term of Return on Total Assets (\%) at significant level less than $(0.001)$ and at significant level greater than (0.05). There is a negative linear relationship between the disclosure attributes voluntary disclosure and financial performance measure in term of Return on Total Assets \% at significant level greater than $(0.05)$. The regression model has $(\mathrm{R} 2=47.40 \%)$ to explain the variation to happen in the Return on Total Assets (\%).

$$
Y 2=0.128 Q 1+0.660 Q 2 *-0.071 Q 3
$$

3. There are significant positive linear relationships between the disclosure attributes voluntary disclosure and financial performance measure in term of Total Assets Growth \% at significant level less than (0.001). The regression model has R2 $=24.30 \%$ to explain the variation to happen in the Total Assets 
Growth \%.

$$
Y 3=0.493 Q 3^{*}
$$

4. There are significant positive linear relationship between the disclosure attribute voluntary disclosure and financial performance measure in term of Net Profit Growth \% at significant level greater than . (0.05) but negative linear relationship between the disclosure attributes corporate governance and audit quality and financial performance measure in term of Net Profit Growth \% at significant level greater than $(0.05)$ and $(0.01)$. The regression model has $\mathrm{R} 2=24.70 \%$ ) to explain the variation to happen in the Net Profit Growth \%.

$$
Y 4=0.384 Q_{1} *-0.171 Q_{2}+0.202 Q_{3}
$$

5. There are significant positive linear relationship between the disclosure attribute corporate governance and financial performance measure in term of Earnings per Share at significant level greater than (0.05) but negative linear relationship between the disclosure attributes voluntary disclosure and financial performance measure in term of Earnings Per Share at significant level greater than (0.05). The regression model has $\mathrm{R} 2=9.60 \%$ to explain the variation to happen in the Earnings per Share.

$$
Y 5=0.104 Q 1+0.246 Q 3
$$

The researcher can conclude from the above results that the financial performance of the two categories, which are the Islamic and non-Islamic banks, affected by different disclosure attributes as shown above which validate the hypothesis of the research.

\section{Measuring the Goodness of Fit of the Islamic and non-Islamic model}

The goodness of fit statistical model tests how well it fits a set of observations. It Measures goodness of fit by summarizing the discrepancy between observed values and the values expected under the model in question.

Table (11): The Goodness of Fit Indices in the SEM

\begin{tabular}{|c|c|}
\hline Chi-Square & 53.163 \\
\hline Degree of Freedom & 16 \\
\hline Level of Significance & 0.001 \\
\hline Normed Chi-Square & 3.323 \\
\hline Root Mean Square Residual (RMR) & 0.071 \\
\hline Goodness of Fit Index (GFI) & 0.918 \\
\hline Adjusted Goodness of Fit Index & 0.63 \\
\hline
\end{tabular}




\begin{tabular}{|c|c|}
\hline (AGFI) & \\
\hline Normed Fit Index (NFI) & 0.903 \\
\hline Relative Fit Index (RFI) & 0.659 \\
\hline Incremental Fit Index (IFI) & 0.930 \\
\hline Tucker Lewis Index (TLI) & 0.734 \\
\hline Comparative Fit Index (CFI) & 0.924 \\
\hline $\begin{array}{c}\text { Root Mean Square Residual } \\
\text { Approximation (RMSEA) }\end{array}$ & 0.135 \\
\hline
\end{tabular}

From table (11), the researcher concluded the following:

All the goodness of fit measures of the model indicate that all indicators at acceptable limits or greater than cut-off values, especially GFI, NFI, RFI, IFI.TLI, and CFI close to one. The fit measures indicate the goodness of fit of the final structural model and its ability to represent the impact of the disclosure attributes corporate governance, audit .quality, and voluntary disclosure on the financial performance of banks (Islamic and non-Islamic) listed in the Egyptian stock exchange market.

\section{HYPOTHESES VERIFICATION:}

The statistical' analysis included many approaches in verifying the research hypothesizes. The descriptive analysis used to determine the mean, percentage, and standard deviation in order to identify the existence of different disclosure attributes in the annual reports of the sample of banks listed in the stock exchange market including the Islamic and non-Islamic banks. The results showed the there are many disclosure attributes are not disclosed by any of the sample like: it approaches used during auditing process, and internal audit reports.

The t-test results showed that the performance measures proposed by the researcher are more significant in favor of measuring the performance of the nonIslamic banks against Islamic banks. There is a significant positive relationship between the corporate governance disclosures attributes and the financial performance of Islamic and non-Islamic banks except for the total asset growth percentage.

Pearson correlation matrix results verified the first and third hypothesizes by proving the positive relationship between disclosures attributes of corporate governance, and voluntary disclosure and the performance measures of Islamic and non-Islamic.

In addition, Pearson correlation matrix proved a negative relationship between the disclosures attributes of audit quality and the performance measures of Islamic 
and non-Islamic, which will reject the second hypothesis of the research.

The multi-group analysis results showed the regression weight of each individual attribute of disclosure for the corporate governance, audit quality, and voluntary disclosure in order to reach the exact nature of impact on the performance of Islamic and non-Islamic banks as it was presented by using the structure equation model in the statistical analysis section of the research.

\section{CONCLUSION}

Given the importance of the banks sector in the national and global macro economy, it is necessary to continuously, improve the disclosure attributes for financial reporting. The main objective of the research was to test the disclosure attributes in the banking sector for the banks listed in the Egyptian stock .exchange market and to measure the impact of these disclosure attributes on the banks financial performance. The research also, classified the sample of the selected banks into Islamic and non-Islamic banks. The research tested the disclosure attributes for the audit quality, corporate governance and voluntary disclosure on the financial performance of the two groups of banks.

This research aimed to grab the attention towards the importance of disclosure attributes of corporate governance, and audit quality along with the voluntary disclosures and their impact on the financial performance of Islamic and nonIslamic banks in the stock exchange market. The research questions of this research have been directed to discuss the impact of the disclosure attributes of corporate governance, audit quality, and voluntary disclosures attributes on the financial performance of Islamic and non-Islamic banks listed in the Egyptian stock market.

The use of multi-group analysis and the path analysis is deemed necessary, as they indicated the impact of the different disclosure attributes on the two groups of the sample, Islamic and non-Islamic banks listed in the stock exchange market. The researcher also, could formulate a regression model to show the effect of the each of the disclosure attributes on the two groups of the sample and used the goodness of fit measures to indicate the fitness of the models in the Egyptian stock exchange market.

The results of the statistical analysis can be summarized as follows:

- There was a positive linear association between the disclosure attributes of corporate governance, and voluntary disclosure and the financial performance of banks listed in the stock exchange market.

- There was a negative linear association between the disclosure attributes of 
audit quality and the financial performance of banks, listed in the stock exchange market.

- There was a significant difference between the Islamic and non-Islamic banks in relation to the disclosure attributes of voluntary disclosure and audit quality.

- There was no significant differences between Islamic and non-Islamic banks in relation to. the disclosure attribute of corporate governance.

\section{References:}

1. Abayo, A...G., \& Roberts, C. B. (1993). Does training more accountants raise the standard of accounting? Further evidence from Tanzania. Research in Third World Accounting, 2, 259-280.

2. Abdel Shahid, S. F. (2001). Corporate Governance is a Global Pursuit: What Could Be Done in Egypt?. Cairo \& Alexandria Stock Exchanges Working Paper, (1).

3. Abdelsalam, O. H., \& Weetman, P. (2007). Measuring accounting disclosure in a period of complex changes: the case of Egypt. Advances in international accounting, 20, 75-104.

4. ACCA (Association of Chartered Certified Accountants) (1999), Improving Business Reporting - A Customer Focus: Meeting the Information Needs of Investors and Creditors, Comprehensive Report of the Special Committee on Financial Reporting.

5. Aebi, V., Sabato, G., \& Schmid, M. (2012). Risk management, corporate governance, and bank performance in the financial crisis. Journal of Banking \& Finance, 36(12), 3213-3226.

6. Aljifri, K. (2008). Annual report disclosure in a developing country: The case of the UAE. Advances in Accounting, 24(1), 93-100.

7. Alkassim, F. A. (2005). The profitability of Islamic and non-Islamic banking in the GCC countries: A comparative research. 13(1), 5-30.

8. Al-Moataz, E., \& Hussainey, K. (2012). Determinants of corporate governance disclosure in Saudi companies. Journal of Economics and Management Journal of Review of Islamic Economics.

9. Al-Razeen, A., \& Karbhari, Y. (2004). Interaction between compulsory and voluntary disclosure in Saudi Arabian corporate annual reports. Managerial Auditing Journal, 19(3), 351-360.

10. Alsaeed, K. (2006). The association between firm-specific characteristics and disclosure: The case of Saudi Arabia. Managerial Auditing Journal, 21(5), 476-496.

11. Armstrong, C. S., Blouin, J. L., Jagolinzer, A. D., \& Larcker, D. F. (2015). Corporate governance, incentives, and tax avoidance. Journal of Accounting and Economics, 60(1), 1-17.

12. Awan, A. G. (2009). Comparison of Islamic and non-Islamic banking in 
Pakistan. Proceedings 2nd CBRC, Lahore, Pakistan, 1-36.

13. Bauwhede, H. V., \& Willekens, M. (2008). Disclosure on corporate governance in the European Union. Corporate Governance: An International Review, 16(2), 101-115.

14. Bedard, J. C., Johnstone, K. M., \& Smith, E. F. (2010). Audit quality indicators: A status update on possible public disclosures and insights from audit practice. Current Issues in Auditing, 4(1), C 12 -C 19.

15. Bédard, J., \& Gendron, Y. (2010). Strengthening the financial reporting system: Can audit committees deliver?. International journal of auditing, 14(2), 174-210.

16. Beretta, S., \& Bozzolan, S. (2008). Quality versus quantity: the case of forward-looking disclosure. Journal of Accounting, Auditing \& Finance, 23(3), 333-376.

17. Blair, M. (1995), Ownership and control: rethinking corporate governance for the twenty-first century, Brookings Institution, Washington DC.

18. Brown, S., \& Hillegeist, S. A. (2003). Disclosure quality and information asymmetry. Kellogg School of Management, Evanston, IL.

19. Bujaki, M.,. \& McConomy, B. J. (2002). Corporate governance: Factors influencing voluntary disclosure by publicly traded Canadian firms. Accounting Perspectives, 1(2), 105.

20. Bushee, B. J. (2004). Discussion of disclosure practices of foreign companies interacting with US markets. Journal of Accounting Research, 509-525.

21. Bushman; R. M., \& Smith, A. J. (2003). Transparency, financial accounting information, and corporate governance. Financial Accounting Information and Corporate Governance. Economic Policy Reviews 9(1).

22. Bushman, R., Chen, Q., Engel, E., \& Smith, A. (2004). Financial accounting information, organizational complexity and corporate governance systems. Journal of Accounting and Economics, 37(2), 167-201.

23. Calabrese, A., Costa, R., Menichini, T., \& Rosati, F. (2013). Does corporate social responsibility hit the mark? A stakeholder oriented methodology for CSR assessment. Knowledge and Process Management, 20(2), 77-89.

24. CAPITAL MARKET LAW No. 95 of 1992.

25. Central Bank of Egypt (1992), Banking and Credit Developments [In Arabic].

26. Central Bank of Egypt, Annual Report 2013-2014

27. Christensen, B. E., Glover, S. M., Omer, T. C., \& Shelley, M. K. (2013). Understanding audit quality: Insights from audit partners and investors. Available at SSRN 2358163.

28. Claessens; S. (2006). Corporate governance and development. The World Bank Research Observer, 21(1), 91-122.

29. Claessens, S., \& Laeven, L. (2005). Financial dependence, banking sector 
competition, and economic growth. Journal of the European Economic Association, 3(1), 179-207.

30. Cooke, T. E. (1989). Voluntary corporate disclosure by Swedish companies. Journal of International Financial Management \& Accounting, 1(2), 171-195.

31. Cooke, T. E. (1991). Experts in uncertainty: opinion and subjective probability in science.

32. Cooke, T. E., \& Wallace, R. O. (1989). Global surveys of corporate disclosure practices and audit firms: a review essay. Accounting and Business Research, 20(77), 47-57.

33. Dahawy, K., Merino, B. D., \& Conover, T. L. (2002). The conflict between IAS disclosure requirements and the secretive culture in Egypt. Advances in international Accounting, 15, 203-228.

34. Debreceny, R., \& Rahman, A. (2005). Firm-specific determinants of continuous corporate disclosures. The International Journal of Accounting, 40(3), 249-278.

35. DeFond, M., \& Zhang, J. (2014). A review of archival auditing research. Journal of Accounting and Economics, 58(2), 275-326.

36. DeZoort, F. T., \& Salterio, S. E. (2001). The effects of corporate governance experience and financial-reporting and audit knowledge on audit committee members' judgments. A Journal of Practice \& Theory, 20(2), 31-47.

37. Dichev, I. D., Graham, J. R., Harvey, C. R., \& Rajgopal, S. (2013). Earnings quality: Evidence from the field. Journal of Accounting and Economics, 56(2), 1-33.

38. Elbannan, M. A., \& Elbannan, M. A. (2015). Economic Consequences of Bank Disclosure in the Financial Statements Before and During the Financial Crisis Evidence From Egypt. Journal of Accounting, Auditing \& Finance, 30(2), 181-217.

39. Firth, M. (1979). The impact of size, stock market listing, and auditors on voluntary disclosure in corporate annual reports. Accounting and Business Research, 9(36), 273-280.

40. Francis, J. R., \& Michas, P. N. (2012). The contagion effect of low-quality audits. The Accounting Review, 88(2), 521-552.

41. Gibbins, M., Richardson, A., \& Waterhouse, J. (1990). The management of corporate financial disclosure: opportunism, ritualism, policies, and processes. Journal of accounting research, 121-143.

42. Gray, S. J., \& Skogsvik, K. (2004). Voluntary disclosures of quoted pharmaceutical companies in Sweden and the UK: The development over the period 1984-98. European Accounting Review, 13(4), 787-805.

43. Grüning, M. (2007). Drivers of corporate disclosure: a structural equation analysis in a Central European setting. Management Research News, 30(9), 646-660.

44. Hanif, M. (2014). Differences and similarities in Islamic and non-Islamic 
banking. International Journal of Business and Social Sciences, 2(2).

45. Hassan, O. A., Romilly, P., Giorgioni, G., \& Power, D. (2009). The value relevance of disclosure: Evidence from the emerging capital market of Egypt. The International Journal of Accounting, 44(1), 79-102.

46. Hossain, M. (1994). Companies Listed on the Kuala Lumpur Stock Exchange. AT URBANA-CHAMPAIGN BOOK STACKS, 29, 334-351.

47. Jensen, M. C., \& Meckling, W. H. (1976). Theory of the firm: Managerial behavior, agency costs and ownership structure. Journal of financial economics, 3(4), 305-360.

48. Kent, P., \& Stewart, J. (2008). Corporate governance and disclosures on the transition to International Financial Reporting Standards. Accounting \& Finance, 48(4), 649-671.

49. Labelle, R. (2002). The statement of corporate governance practices (SCGP), a voluntary disclosure and corporate governance perspective. Journal of corporate governance.

50. Laeven, L., \& Levine, R. (2009). Bank governance, regulation and risk taking. Journal of Financial Economics, 93(2), 259-275.

51. Law No. 80 of $\mathbf{2 0 0 2}$ promulgating the Anti-Money Laundering Law

52. Law No. 88 of the 2002 CBE Act. Modified by law No. 125 of 2011.

53. Mehran, H., Morrison, A. D., \& Shapiro, J. D. (2011). Corporate governance and banks: What have we learned from the financial crisis?. FRB of New York Staff Report, (502).

54. Muhamad, R., Shahimi, S., Yahya, Y., \& Mahzan, N. (2009). Disclosure quality on governance issues in annual reports of Malaysian PLCs. International business research, 2(4), p 61.

55. Raffournier, B. (1995). The determinants of voluntary financial disclosure by Swiss listed companies. European accounting review, 4(2), 261-280.

56. Ragothaman, S., Mock, T. J., \& Srivastava, R. P. (2014). A Review and Evaluation of Audit Quality Oversight. Indian Accounting Review.

57. Rizk, R., Dixon, R., \& Woodhead, A. (2008). Corporate social and environmental reporting: a survey of disclosure practices in Egypt. Social Responsibility Journal, 4(3), 306-323.

58. Samaha, K., \& Dahawy, K. (2010). An empirical analysis of corporate governance structures and voluntary corporate disclosure in volatile capital markets: The Egyptian experience. International Journal of Accounting, Auditing and Performance Evaluation, 7(1-2), 61-93.

59. Samaha, K., \& Dahawy, K. (2011). An empirical analysis of corporate governance structures and voluntary corporate disclosure in volatile capital markets: The Egyptian experience. International Journal of Accounting, Auditing and Performance Evaluation, 7,61-93 Nos. 1/2.

60. Samaha, K., Dahawy, K., Hussainey, K., \& Stapleton, P. (2012). The extent of corporate governance disclosure and its determinants in a developing market: The case of Egypt. Advances in Accounting, 28(1), 168-178. 
61. Shleifer, A., \& Vishny, R. W. (1997). A survey of corporate governance. The journal of finance, 52(2), 737-783.

62. Singhvi, S. S., \& Desai, H. B. (1971). An empirical analysis of the quality of corporate financial disclosure. Accounting review, 129-138.

63. Soliman, M.M. (2013), "Firm Characteristics and the extent of voluntary disclosure: the case of Egypt", Research Journal of Finance \& Accounting, vol. 4 , issue. 17 , pp. 71-81. 